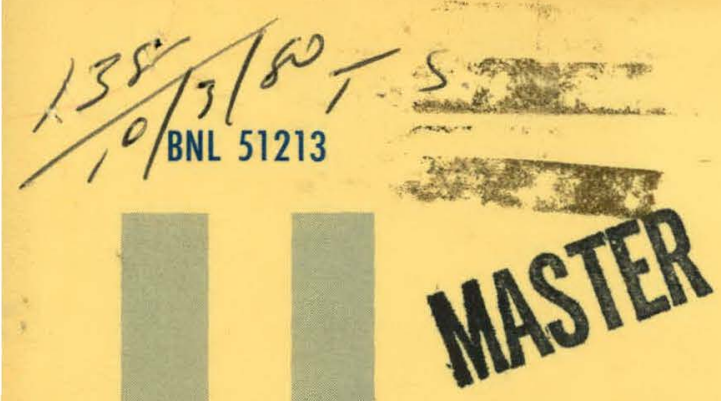

\title{
ENERGY CONSERVATION IN TWO NORTHEASTERN CITIES: OPPORTUNITIES, PROBLEMS, AND PROSPECTS
}

\author{
F.C. BRYANT AND P.D. Moskowitz
}

October 1979

RESEARCH SPONSORED BY THE

DIVISION OF TECHNOLOGY ASSESSMENTS

OFFICE OF TECHNOLOGY IMPACTS

OFFICF OF THE ASSISTANT SECRETARY FOR ENVIRONMENT UNITED STATES DEPARTMENT OF ENERGY

DIVISION OF REGIONAL STUDIES

NATIONAL CENTER FOR ANALYSIS OF ENERGY SYSTEMS

BROOKHAVEN NATIONAL LABORATORY

UPTON, NEW YORK 11973 


\section{DISCLAIMER}

This report was prepared as an account of work sponsored by an agency of the United States Government. Neither the United States Government nor any agency Thereof, nor any of their employees, makes any warranty, express or implied, or assumes any legal liability or responsibility for the accuracy, completeness, or usefulness of any information, apparatus, product, or process disclosed, or represents that its use would not infringe privately owned rights. Reference herein to any specific commercial product, process, or service by trade name, trademark, manufacturer, or otherwise does not necessarily constitute or imply its endorsement, recommendation, or favoring by the United States Government or any agency thereof. The views and opinions of authors expressed herein do not necessarily state or reflect those of the United States Government or any agency thereof. 


\section{DISCLAIMER}

Portions of this document may be illegible in electronic image products. Images are produced from the best available original document. 
BNL 51213

UC-95a

(Energy Conservation-Utilization and Information Dissemination - TIC-4500)

\title{
ENERGY CONSERVATION IN TWO NORTHEASTERN CITIES: OPPORTUNITIES, PROBLEMS, AND PROSPECTS
}

\author{
F.C. Bryant and P.D. Moskowitz
}

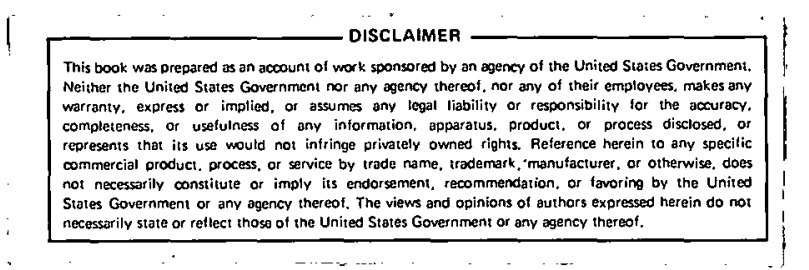

October 1979

\author{
RESEARCH SPONSORED BY THE \\ DIVISION OF TECHNOLOGY ASSESSMENTS \\ OFFICE OF TECHNOLOGY IMPACTS \\ OFFICE OF THE ASSISTANT SECRETARY FOR ENVIRONMENT \\ UNITED STATES DEPARTMENT OF ENERGY
}
NATIONAL CENTER FOR ANALYYSIS OF ENERGY SYSTEMS BROOKHAVEN NATIONAL LABORATORY ASSOCIATED UNIVERSITIES, INC. UPTON, NEW YORK 11973

UNDER CONTRACT NO. DE-AC02-76CHOOO16 WITH THE UNITED STATES DEPARTMENT OF ENERGY 


\section{DISCLAIMER}

This book was prepared as an account of work sponsored by an agency of the United States Guverinment. Nither the United Etates Guveriment nuir ainy agcincy thereof, nor any of their employees, makes any warranty, express or implied, or assumes any legal liability or responsibility for the accuracy, completeness, or usefulness of any information, apparatus, product, or process disclosed, or represents that its use would not infringe privately nwned rights. Reference herein to any specific conmmercial product, process, or service by trade name, trademark, manufacturer, or otherwise, does not necessarily constitute or imply its endorsement, recommendation, or favọing by the United States Government or any agency thereof. The views and opinions of authors expressed herein do not necessarily state or reflect those of the United States Government or any agency thereof.

Printed in the United States of America Available from

National Technical Information Service

U.S. Department of Commerce

5285 Port Royal Road

Springfield, VA 22161

Price: Printed Copy $\$ 4.50$; Microfiche $\$ 3.00$ 


\section{ABSTRACT}

Policy assessment of energy conservation strategies has tended to emphasize technological and economic costs, problems, and benefits. However, too narrow a focus may fail to delineate all the environmental and social impacts associated with the technology in question. In recognition of the importance of a balanced evaluation, a study was undertaken to identify local-level perceptions about environmental and social problems and opportunities associated with several energy conservation measures. These measures included building performance standards and retrofit; waste heat utilization; modifications in land use configurations and transportation modes; and electric utility demand management and rate reform initiatives. The perceptions were identified by interviewing 55 officials, planners, and members of business and citizen groups in Erie, Philadelphia, and Harrisburg (the capital), Pennsylvania. Results of the study indicate that implementation of the energy conservation measures under investigation faces political, economic, and social barriers of varying dimensions. Major among these are the constraints felt to be imposed by a declining economy and the resulting concern with attracting and holding business and industry. 
TABLE OF CONTENTS

Abstract...................................

Acknowl edgments $\ldots \ldots \ldots \ldots \ldots \ldots \ldots \ldots \ldots \ldots \ldots \ldots \ldots \ldots \ldots \ldots \ldots \ldots \ldots$

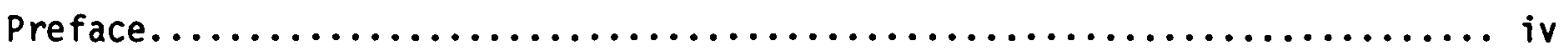

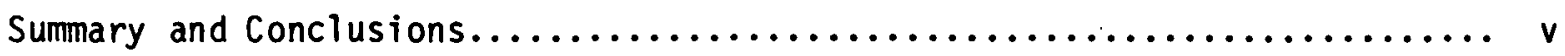

Introduction: Background and objectives...................... 1

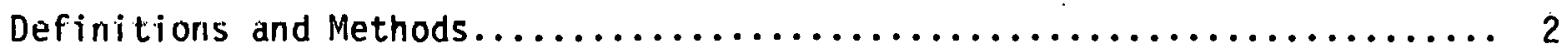

Pennsylvania: A Slate Overview............................ 4 Residential Weatherization for Low Income Households............. 5

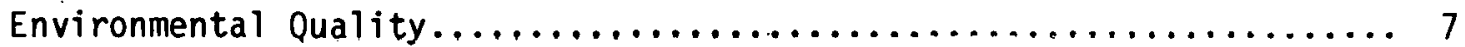
[lectric Ulilily Rate Structure........................ 8

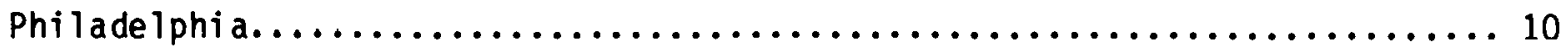

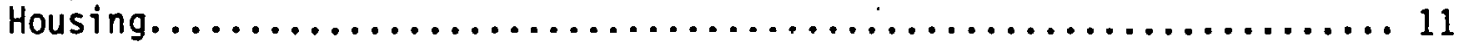

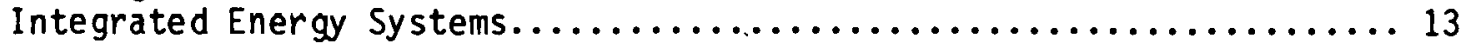

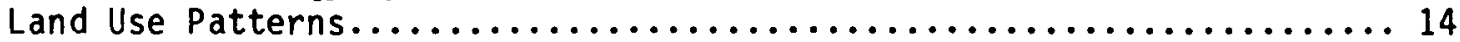

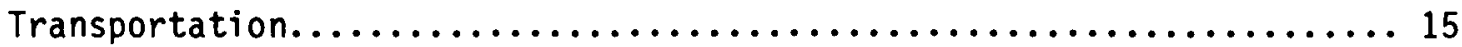

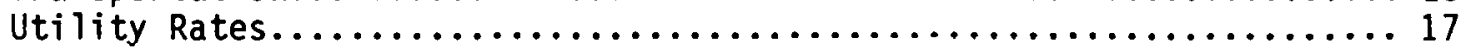

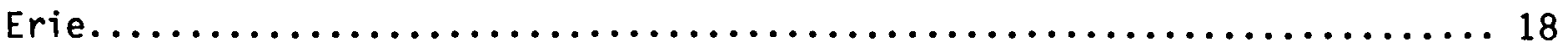

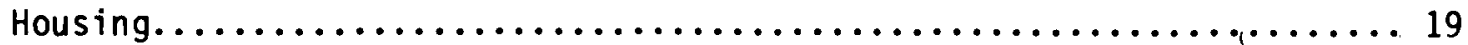

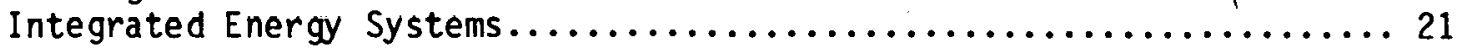

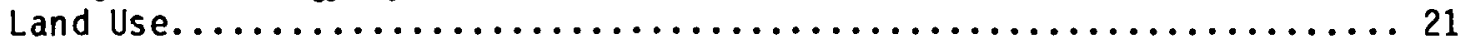

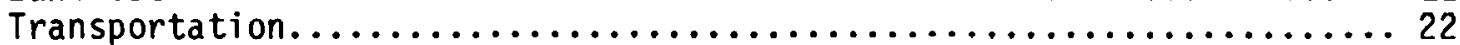

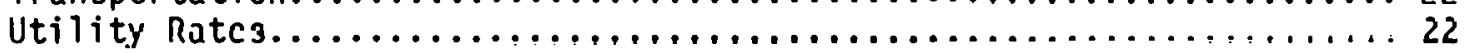

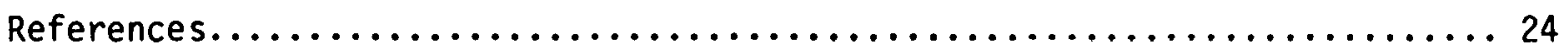

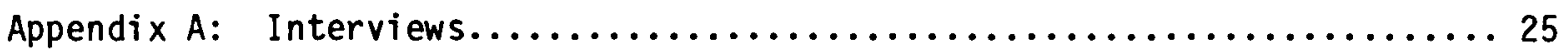

Appendix B: Letter and Enclosures Sent to Interviewees............. 26

Appendix C: Regional, State, and Local Enerqy Perșpectives............. 31 
PREFACE

The Office of the Assistant Secretary for Environment, in the U.S. Department of Energy's Division of Technology Assessments, is charged with assessing energy technologies to assist in formulating policy, defining environmental concerns and research priorities, and providing an information base for use in carrying out other DOE responsibilities. To these ends, the Division of Technology Assessments has sponsored coordinated research at Brookhaven National Laboratory and at Battelle Pacific Northwest Laboratories aimed at identifying and evaluating environmental and social benefits, costs, problems, and uncertainties associated with several emerging energy conservation technologies. This report presents the results of but one part of this larger effort. Other project reports completed to date include the following:

- Paul D. Moskowitz, Tien Q. Le, and Barbara Pierce, "Ranking Energy Conservation Measures to Establish Research Priorities: Synopsis of a Workshop," BNL 51046, May 1979.

- Paul D. Moskowitz, Edward Edelson, Tien Q. Le, Walter A. Sevian, Joseph Smith, and Alan Struth, "Energy-Environmental Impacts of Five Energy Conservation Strategies in the Middle Atlantic and Pacific States," BNL 51110, Oct. 1979.

- Edward Edelson and Marvin 01sen, "Potential Environmental and Social Impacts of Selected Energy Conservation Measures in Two Washington Communities," PNL-RAD-39, Sept. 1979.

- Paul D. Moskowitz and Edward Edelson, "Preliminary Technology Assessment of Selected Energy Conservation Measures: Issues and Research Needs," Nov. 1979, to be published by the Division of Technology Assessments, U.S. DOE, Washington, DC. 


\section{ACKNOWLEDGMENTS}

We are indebted to Robert Blaunstein, Vary Coates, Fred Lipfert, Peter Meier, and David Moses for their constructive guidance and comments throughout all phases of this effort. We also wish to thank Connie Barnard-Murray, Betty Burke, Laine Harris McCarthy, and Patricia Miller for their assistance.

The study reported here is based on a series of interviews with officials and citizens in Harrisburg, Philadelphia, and Erie, PA. We thank all thnsp who gave their time to participate in this study. In our use of puhlisher information and material collected at these interviews, we have made every effort to report the findings and local perspectives as fully and accurately as possible, but we have not been able to present and fully discuss all the information or viewpoints expressed by all interviewees. Thus, selections and generalizations had to be made, and the perspectives, findings, and conclusions presented in this report are therefore solely the responsibility of the authors. 
Summarized below are outlines of activities, prospects, and perceptions in Philadelphia and Erie related to the implementation of the energy conservation measures under consideration in this report. In the use of published information and materials collected at interviews, every effort has been made to report the findings and local perspectives as fully and accurately as possible. It was not possible, however, to present and fully discuss all the information and viewpoints expressed by all interviewees. Furthermore, their perceptions need not necessarily reflect those of the general public. Thus, selections and generalizations had to be made, and the perspectives, findings, and conclusions presented in this report are therefore solely the responsibility of the authors.

HOUSING

Neither Philadelphia nor Erie currently incorporates energy performance standards in its building codes, and neither city plans to do so in the near future. The stated reasons in both cases are primarily economic: most northeastern cities are in economic decline or stagnation and are therefore reluctant to impose any new costs that might discourage economic and industrial growth. By the same token, however, the energy savings to be realized from imposing such standards in these cities are possibly limited, for new building construction is not proceeding at a rapid rate in either city. Rather, in the respondent's view, the larger potential for energy savings in the residential sectors lies in the retrofit of existing housing. The primary barriers to extensive retrofitting are political, social, and economic. Retrofitting requires the cooperation if not the initiative of individual homeowners, many of whom are reluctant or unable to bear the front-end costs of installing insulation, weatherstripping, and so forth.

In both Philadelphia and Erie the major programs directed toward encouraging the retrofit of existing housing are the local weatherization programs. Although these welfare-cum-energy conservation programs face problems that vary in detail from city to city, all are underfunded and are therefore unable to retrofit the homes of all potentially eligible persons. A focal problem is the assigning of priorities -- to, say, the elderly or to homeowners -- and the resolution of the social equity issues that inevitably arise from any such assignments. 
For income groups other than the lowest, the retrofit of existing housing is primarily or exclusively a private concern. Reliable data are not available on the rates at which middle and upper income homes are currently being retrofitted, and on the nature of the major barriers to retrofitting in the private sector in each city, or the problems encountered.

\section{INTEGRATED ENERGY SYSTEMS}

Large numbers of home and commercial facilities are located near electric power plants in Erie and Philadelphia, yet the number of district heating customers in both these service areas continues to decline. Likewise, capabilities within the industries of these cities to cogenerate electricity remain largely unexploited. The concept of integrated community energy systems (ICES) is only now being considered for some of the large new malls and other commercial buildings being planned. Technical, regulatory, and economic barriers appear to be the major obstacles limiting further use of cogeneration. Environmental issues appear to be a second-order concern; in fact it is generally believed that use of waste heat could marginally improve air quality by increasing the overall efficiency of energy use and concomitantly decreasing environmental emissions. Concern was expressed over source control requirements. State officials believed that it would be far simpler to regulate emissions from several large facilities than from many small ones. This concern applies to all technologies involved with waste heat utilization. It relates to environmental emissions to the extent that the control requirements may vary for small and large facilities; in general, smaller facilities emit larger quantities of pollutants per Btu consumed and thus may have greater environmental impacts.

\section{LAND USE PATTERNS}

Both the Erie and the Philadelphia Standard Metropolitan Statistical Areas, in recent decades, have undergone progressive suburbanization. This has had major consequences for energy use, for it typically involves scattered single-family housing and regular commuting over long distances by private automobile. The energy inefficiencies associated with this pattern are of concern among community leaders in both areas; hut changes in current patterns and trends are thought to face serious impediments, particularly in the Erie area, which has little or no planning and transportation infrastructure to support alternative land use patterning. In both areas, heavy economic and 
psychological investment in current lifestyles, coupled with the aspirations of many suburban areas for continued economic development, will probably prove to be major obstacles to the realization of more energy efficient settlement patterns.

TRANSPORTATION

Philadelphia has a highly developed mass transportation system consisting of buses, trolleys, subways, and commuter railways. This system is operating at near capacity, and its expansion would require major renovations and capital expenditures because of rolling stock and line limitations. In Erie, in contrast, mass transportation consists of a limited but under-utilized bus system.

While the growth of mass transportation in these two cities thus faces contrasting kinds of problems and opportunities, continued growth at the suburban fringes ensures that the region will continue to depend largely on private automobiles. In Philadelphia, innovative strategies are being deployed to reduce the vehicle miles traveled by these automobiles and thereby to reduce gasoline consumption; these include car and van pooling, parking management programs, and expressway bus and car pool lanes. Beneficial effects on air quality are expected to result from these measures; but state and city officials expect these to be minimal. Most air quality improvements are instead expected to come from a vehicle inspection and maintenance program, the fuel use impact of which is not yet known. In Erie, mobile source emissions are not as critical a problem; therefore, alternative transportation management strategies are not being as closely scrutinized.

\section{UTILITY RNTES}

The Philadelphia Electric Company and the Pennsylvania Electric Company, the electric utilities serving the Philadelphia and Erie areas, are each currently experimenting with a number of innovative rate structures designed to curtail peak demand. These include, for example, demand metered rates, seasonal peak pricing, controlled water heating tariffs, and time-of-day rates. Inverted block pricing, however, a rate structure aimed at curtailment of use rather than load management, and its social welfare oriented variant, lifeline rates, are not favored by either utility on the grounds that rate structures should be based on cost of service. This general stance is supported by the Pennsylvania Public Utilities Commission. 
Philadelphia's and Erie's gas utilities, Philadelphia Gas Works and National Fuel Gas Company, are also opposed to inversion of the declining block pricing structure. For them, load management schemes are not at issue.

In both Philadelphia and Erie, rising energy costs have made utility rate reform a politically sensitive issue. In Erie, for example, consumer, union, and environmentalist groups are advocating municipal ownership of utilities, arguing that changes in rate structures alone do not go far enough. Given the politicized context of utility rate-making, it seems unlikely that economic and energy conservation considerations will be the sole criteria governing the design and evaluation of rate alternatives.

\section{OVERV IEW}

As seen from this summary, despite numerous differences between Philadelphia and Erie, implementation of the energy conservation measures under consideration faces political, economic, and social barriers that are similar in broad outline in the two areas. Major constraints are seen to be imposed by a declining regional economy and the resulting concern with attracting and holding business and industry. In the view of many interviewees, Philadelphia and Erie simply cannot afford, say, to adopt mandatory energy efficiency standards for buildings and homes, or to discourage automobile commuting by not providing central city parking, because these and many other energy conservation measures might increase costs or in other ways make these cities less attractive to industry. Portland, Oregon, a city with a growing jujulaliun dill economy that is considering the adoption of stringent energy conservation standards, was frequently cited as an example of a contrasting case. It was also pointed out that Portland, relying chiefly on cheap hydropower systems having little capacity for futher development, has more incentive to conserve energy than does Philadelphia, where the Philadelphia Electric Company currently has excess capacity. Thus, in the view of these informants, the distinctions with the most important implications for energy conservation are not those between Philadelphia and Erie but rather those between the Northeast and other regions of the country. 


\section{INTRODUCTION: BACKGROUND AND OBJECTIVES}

Policy assessment of energy conservation strategies has tended to emphasize technological and economic costs, problems, and benefits. But too narrow a focus on energy savings per dollar cost for a conservation technology may fail to anticipate and delineate all of the environmental and social impacts associated with the technology in question. As a result, critical policy ramifications may not be adequately assessed and weighed in the policy-making process. Recognizing the importance of a balanced evaluation of a range of technology costs and benefits extending beyond the economic and the technological, the Regional Studies Division of the National Center for the Analysis of Energy Systems (NCAES), Brookhaven National Laboratory, with support from the Office of the Assistant Secretary for Environment, Division of Technology Assessments, U.S. Department of Energy, has undertaken this study of locallevel environmental and social problems and opportunities associated with several energy conservation measures.

Five energy conservation measures or strategies were selected for study: (1) energy performance standards for new buildings, and retrofit of residential and commercial builings; (2) district heating, cogeneration, and integrated community energy systems (ICES); (3) changes in land use configurations; (4) changes in transportation modes; and (5) electric load demand management and utility rate reform. This selection was based on consideration of a number of criteria and objectives which emerged from a workshop held in April 1979 with participants from all parts of the country representing diverse interests and perspectives.1 The criteria were the following: each of the five measures offers substantial potential for energy savings; ${ }^{2}$ (2) taken together, they affect all major energy use sectors--residential, industrial, commercial, transportation, and utilities; and (3) together they present a spectrum of implementation strategies and of possible environmental and social constraints and opportunities.

The research effort was designed to explore the nature of the actual environmental and social settings in which these strategies could be implemented and to delineate the energy conservation opportunities and constraints inherent in these settings. Philadelphia and Erie, Pennsylvania, each unique but also representative in many respects of problems and conditions in large and middle-sized cities throughout the Northeastern United States, were selected for study. Fifty-five interviews were conducted with officials, 
planners, and members of business, industrial, and citizens' groups in the two cities, and with officials of several state offices and agencies in Harrisburg, the state capital.

The study was designed as a preliminary and exploratory effort. The report therefore offers neither firm findings nor definite conclusions. Rather, the outlines of potential environmental and social costs and benefits of energy conservation are traced in two northeastern cities, and regional implications for energy conservation in the Northeast are drawn and discussed. In the use of published information and materials collected at these interviews, every effort was made to report the findings and local perspectives as fully dnd accurately as possible. It was impossible, however, to present and fully discuss all the information and viewpoints expressed by all interviewees. Furthermore, their perceptions necd not necessarily reflect. those of the general public. Thus, selections and generalizations had to be made, and the perspectives, findings, and conclusions presented in this report are solely the responsibility of the authors.

DEFINITIONS AND METHODS

This report explores selected perceptions of social and environmental impacts of several energy conservation measures in the cities of Philadelphia and Erie, Pennsylvania.

Fnvironmental impacts are defined as costs, benefits, constraints, or opportunities associated with changes in the natural ellvironment. For the purposes of this study, environmental changes having significant and relatively immediate health and safety implications, especially those of air quality, received particular attention.

Social impacts are in practice often treated as a residual category. As used in policy assessment studies, this category tends to encompass a disparate assortment of concerns and issues united chiefly by the fact that they are normally not included within the standard rubrics of technological, economic, institutional, envirumitiental, and health and safely impacts. In this study, however, a more focused perspective was adopted, and the highlighted issues and concerns are those perceived by the interviewees to involve considerations of snrial equity, that is, of the distribution and redistribution of both tangible and intangible wealth, goods, amenities, and satisfactions within and among social groups and classes. 
These issues are evaluated within the context of environmental and social conditions and trends in two Pennsylvania cities. Philadelphia and Erie were selected because (a) in size, population density, and character they are reasonably representative of large and middle-sized urban areas in the Northeast, and (b) each appears to offer some potential and scope for implementation of the conservation measures under study.

Research was conducted through a series of interviews with individuals affiliated with diverse agencies, organizations, and groups concerned with energy conservation issues in Philadelphia and Erie. The agencies and groups contacted in each city ranged from a small business minority construction enterprise specializing in housing retrofit work in minority neighborhoods, to large utilities, to a county office of the state's Department of Environmental Protection. In order to place the information derived from these interviews within the context of statewide perspectives, concerns, and activities related to energy conservation, officials of several state agencies were interviewed in Harrisburg, the Pennsylvania state capital. Figures pertaining to the numbers of individuals interviewed in each city and categorical descriptions of the agencies and organizations with which interviewees were affiliated are provided in Appendix A.

Prospective interviewees were initially contacted by telephone. Agencies and organizations that appeared likely to deal with or to have some interest in the conservation strategies to be investigated were contacted first. Examples of such organizations include electric and gas utilities, community action agencies, environmental agencies and interest groups, and local and regional planning bodies. Individuals thus contacted in turn suggested others who they thought could contribute to the study. In this manncr, the rough outlines of an "energy community" composed of people involved in energyrelated concerns and activities were soon identified in each city. In Erie and especially in Philadelphia, these energy communities proved to be quite large, and time and funds did not permit interviewing everyone who could have made significant contributions to this study. Interviewees were therefore selected with a view to obtaining as wide as possible a spectrum of interests and perspectives. Appointments for interviews were arranged by telephone or mail, and letters explaining the focus and objectives of the study were sent to prospective interviewees. A sample of this letter and its attachments is provided in Appendix B. 
As the selection process suggests, efforts were made to interview persons having knowledge and experience both of local conditions and of one or more of the energy conservation strategies under study. The research was not designed as an attitudinal survey or opinion poll. Its aim was an evaluation, based on local knowledge, of the opportunities and problems confronting the implementation of selected energy conservation strategies in two Northeastern cities. The interviews were unstructured but focused on general topics and issues such as the following:

- What kinds of conservation-related programs and activities are currently underway? What kinds of problems have arisen and what had been the major benefits or successes of these activities? In what way might these programs be improved?

- What have been or might be the major local benefits of implemenation or fuller implementation of each strategy, and why?

- What kinds of problems, barriers, or uncertainties are likely to be associated with the local implementation or fuller implementation of each measure, and why?

Throughout the interviews, an effort was made to elicit interviewees' candid responses and appraisals in addition to official stances. To this end, interviewees were assured of anonymity and a tape recorder was not used. Most interviewees spoke as knowledgeable citizens with special experience or perspectives rather than as company, agency, or group spokespeople. This report, then, is based on evaluations of the perceptions expressed by a number of persons, perceptions shaped in each case by the person's affiliation with, for example, a citizens' environmental group, a labor union, a utility, a chamber of commerce, or a local welfare or community action agency.

The three sections immediately following focus on straight reportage of the results of the interviews, first in Harrisburg, second in Philadelphia, and third in Erie. Occasional commentary and analysis are introduced, but general comparisons and analyses are presented in, the summary and conclusions. Appendix $C$ presents overviews of regional, state, and local energy perspectives.

\section{PENNSYLVANIA: A STATE OVERVIEW}

This section is based on interviews with 20 officials of 5 state departments or agencies in Harrisburg, Pennsylvania, and on state government docu- 
ments or publications made available during or following these interviews. The material derived from these interviews does not fit neatly into any consistent presentational format based on conservation strategies, on energy use sectors, or on areas of impact. What emerged, rather, were three areas of state concern and program activity that were closely related to the subject and focus of this investigation. These are, briefly, the welfare crisis resulting from rapidly rising energy prices, the environmental costs and benefits of energy conservation, and the regulation of public utilities. State programs, activities, and perspectives associated with these topics and issues are discussed under the following subsections: Residential Weatherization Programs for Low Income Households, Environmental Quality, and Utility Rate Structures.

RESIDENTIAL WEATHERIZATION FOR LOW INCOME HOUSEHOLDS

Pennsylvania's weatherization programs are administered by the office of Community Energy in the state's Department of Community Affairs. The Pennsy1vania program is a recognized leader in weatherization, and the office of Community Energy is currently under contract with the U.S. Department of Energy to provide management training to other weatherization programs throughout Federal Region III (Maryland, Delaware, Virginia, West Virginia, Pennsylvania, and the District of Columbia).

Services and materials provided under the program at present include ceiling insulation, caulking, storm windows, and insulation around hot water heaters where applicable. Boiler retrofitting is under consideration, and the Office of Community Energy, in conjunction with a Philadelphia oil dealer, is initiating a small-scale experimental boiler retrofitting program in Philadelphia in the fall of 1979.

Since the program's inception, almost 40,000 homes have been retrofitted. The program achieves an estimated $25 \%$ reduction in heating fuel use per house, resulting in the saving of more than 268,600 barrels of oil and a money saving of about $\$ 4.8 \mathrm{million}$ for the state's low income families. The office of Community Energy, which has provided these estimates, cautions however that they are of necessity based on spotty and somewhat subjective assessments. Given present priorities and funding levels and given the practical problems of obtaining the necessary client cooperation, carefully controlled beforeand-after energy audits often are not feasible and, therefore, not completed. 
Eligibility for the weatherization program is established on the basis of federally set income criteria as follows:

\begin{tabular}{|c|c|c|}
\hline No. of per & Yearly income & Monthly income \\
\hline $\begin{array}{r}1 \\
2 \\
3 \\
4 \\
5 \\
6 \\
>6\end{array}$ & $\begin{array}{c}\$ 4,250 \\
5,626 \\
7,000 \\
8,375 \\
9,750 \\
11,125 \\
\text { add } 1,375 \text { /person }\end{array}$ & $\begin{array}{r}\$ 354 \\
469 \\
583 \\
698 \\
813 \\
927 \\
\text { add } 106 / \text { person }\end{array}$ \\
\hline
\end{tabular}

To promote and facilitate responsiveness to the unique needs and problems of the local situation, the setting of other eligibility prinrities has hepn left to the discretion of each of the bb local agencies that administer and implement Pennsylvania's weatherization programs. One unfortunate result has. been the de facto exclusion of renters due to a myriad of perceived practical and political problems centering about the issue of how best to benefit the tenant without providing the landlord an unwarranted subsidy (how, for example, to ensure that the landlord does not raise the rent in response to enhanced property value). Of the 18,786 Pennsylvania homes retrofitted under the 1978 weatherization program, on ly 785, or $4.2 \%$, were renter occupied.

Barriers to the inclusion of renters are not confined to Pennsylvania: renters have generally been overlooked in weatherization programs throughout the country. This has provoked considerable criticism:

"Low income renters are generally among the poorest of the Nation's poverty population and recent statistics show that they constitute more than half those eligible for the weatherization program." 3 "Systematically avoiding renters amounts to discrimination ... and quite simply, qualified renters are legally entitled to this service."4

In response to these perceived inequities, the Federal Government now requires that all weatherization programs include at least $25 \%$ rental units as of July 1, 1979. This is expected to eliminate some of the inequities of the programs. Nevertheless, program administrators in Pennsylvania are concerned about a number of remaining problems and inequities, some probably generic to weatherization programs throughout the country and others specific to conditions in Pennsylvania. These include the following:

1. Federal income criteria of $125 \%$ of the federal poverty level (see above) were set some years ago and do not adequately reflect present condi- 
tions and energy prices. The circumstances of a great many poverty households with higher incomes warrant federal assistance through the weatherization program. Also, the program fails to deal with those among the working poor who have been severely pressed by recent sharp rises in energy costs and who do not have the disposable income for the building and furnace retrofits necessary to effect significant reductions in their fuel requirements.

2. Uniform nationwide income criteria ignore regional disparities in the cost of living. Also, within Pennsylvania, significant cost-of-living disparities are apparent between rural and urban areas. In failing to incorporate procedures for local or regional income criteria adjustments, the weatherization program effectively discriminates against the Northeast and particularly against northeastern city dwellers.

3. Program coverage is greatly constrained both by limited funding and by the size of the available CETA work force, which is pegged to state unemployment levels and not to number of eligible weatherization program applicants.

These problems and inequities are particularly serious in view of rapidly rising energy costs. Many interviewees anticipate that numerous freezing deaths will occur in Pennsylvania in the coming winter and that many families, without sufficient funds to purchase heating $0 i 1$, will instead invest in inexpensive electric heaters. Hence, achievement of the weatherization program's goal--reducing fuel costs to low-income households by reducing fuel requirements--is thought by many in Pennsylvania to be imperative from the perspectives both of energy conservation and of social justice.

ENV IRONMENTAL QUALITY

Pennsylvania is the most industrialized state in the Northeast, and this has had important consequences on air quality. Although air quality has improved within the state in recent decades as source control requirements were tightened, large areas are still in non-compliance with many of the National Ambient Air Quality Standards. According to state officials, motor vehicle emissions controls will have to play a major role in attempts to achieve compliance.

Many counties fail to meet the federal standards for sulfur oxides and particulates, for example. Most of these problems are believed to result from local industrial sources, but transportation sector emissions and long-range transport from neighboring states are also of concern. State officials 
suggest that attainment status for these pollutants will probably be sought primarily through transportation controls, for it is believed that pointsource controls cannot be tightened further without incurring serious adverse economic consequences.

For oxidants, the problem is more critical. No county within the entire state is in compliance with the oxidant standard, although the data show recent declines in the number of violations encountered. In contrast to other atmospheric pollutants, oxidants are the products of regionwide emissions of hydrocarbon and nitrogen oxides, and oxidant levels are therefore not greatly influenced by isolated attempts at local emissions control. State officials therefore belleve that only programs implemented on a regionwide basis, such as uniform requirements for the inspection and maintenance of motor vehicles, can be expected to reduce oxidant levels significantly.

\section{ELECTRIC UTILITY. RATE STRUCTURE}

Average and peak electrical demand has steadily risen in Pennsylvania during the past two decades: Per capita use of electricity has grown more rapidly in Pennsylvania than nationwide.

In June 1976, the Pennsylvania Legislature adopted Joint Concurrent Resolution No. 228 directing the Pennsylvania Public Utilities Commission (PUC) to undertake an investigation of alternative utility rate structures "which might tend to discourage increased consumption of electricity." The PUC's subsequent investigation entailed 57 days of evidentiary hearings in Harrisburg and non-evidentiary hearings in 24 communities throughout the comonwealth. The final report 5 prepared by the PUC discusses a wide variety of rate structures and designs, including the following:

Discount prices to customers who decrease their electricity consumption.

Inversion of the declining block rate pricing structure.

Time-of-day pricing.

Seasonal peak pricing (for summer peaking utilities).

Marginal cost pricing.

Rates based on electricity price elasticity.

Special rates for large residential users.

Life-line rates.

Interruptible, off-peak, and curtailable service rates.

Rates based on KVA demand pricing.

Demand metered or demand limited residential rates. 
Recommendations efrerging from the PUC study can be summarized as follows:

1. Electric rate structures in the Commonwealth should be based on cost of service principles.*

2. To reduce energy use, demand averaging techniques and all declining block and preferential rates should be phased out.

3. To reduce energy demand, optional time-of-day (on an experimental basis), load factor, off-peak, interruptible, combination firm-interruptible, and curtailable rates should be offered.

The subject of utility rate design has attracted widespread interest in Pennsylvania, and numerous individuals, representing diverse business and industrial interests, utilities, consumer groups, environmental organizations, and federal and state agencies, participated in the Commission's hearings. Most of the investigation focused on examination of the economic merits and demerits associated with the rate measures under consideration. The social component, however, was not neglected and arose particularly with reference to rates for large residential users and life-line rates to provide small amounts of electricity at low prices, both politically volatile issues.

With regard to the first, it was suggested by several interviewees that pricing policies that seek to penalize large (and presumably wasteful) electricity users would have inequitable and unjust impacts. Figures from a Metropolitan Edison study, for example, indicated that most large residential use in their service area was related either to all-electric homes or to the presence of associated agricultural activities.

With regard to life-line rates, four Pennsylvania studies (by Duquesne Light, Pennsylvania Electric, Pennsylvania Power and Light, and Philadelphia Electric) suggest that income level and level of energy use are not as directly related as is sumetimes assumed and that many factors in addition to income (family size, for example) have significant impacts on energy use. Within its service area, the Philadelphia Electric Company found that "a large majority $(70 \%)$ of low electrical users are above the poverty level" and that "among poverty families, only $37 \%$ are 'low' electrical users, while $57 \%$ are 'medium' electrical users." As a result, the PUC suggests, life-line rates are difficult to "target" and would often benefit many people for whom they are not intended (i.e., low energy users with relatively high incomes) while imposing additional hardships on numerous low-income families requiring large amounts of electricity.

*This and subsequent quotations in this section are from the PUC report, 5 which lacks page numbers. 
These and many other findings and recommendations resulting from the PUC hearings and investigation have been subject to debate and dissension among various interest groups.

\section{PHILADELPHIA}

Philadelphia, the largest city in Pennsylvania and the fourth largest city in the United States, is a consolidated city/county with a land area of 12.9 square miles and a 1975 population of $1,815,808$. It is the central city of an eight-county Standard Metropolitan Statistical Area (SMSA) having a 1975 population of 4,807,001 and comprising (in addition to Philadelphia), Bucks, Chester, Delaware, and Montgomery Counties in Pennsylvania and Burlington, Camden, and Gloucester Counties in southwestern New Jersey.

While the population of the entire Philadelphia SMSA grew by $10.9 \%$ from 1960 to 1970, that of the city of Philadelphia declined By $2.9 \%$. The progressive suburbanization of the population, an upper and middle income group exodus from the city, is reflected in a growing urban concentration of nonwhites (from $26.7 \%$ in 1960 to $33.6 \%$ in $1970^{\star}$ ) and of the elderly, age 65 and older (from $10.4 \%$ in 1960 to $11.7 \%$ in 1970), two relatively less mobile socioeconomic groups.

According to the 1979 Pennsylvania County Industry Report for Philadelphia County, Philadelphia ranked first among the state's counties in manufacturing employment $(145,698$ employees $)$ and value produced $(\$ 9,393,594,000)$ in 1976. The 1970 U.S. Census put Philadelphia City/County total employment at. 763,520 of which 214,965 (28\%) were employed in manufacturing, followed by retail trade $(16 \%)$ and public administration $(8 \%)$. The leading manufacturing industries in terms of employment are food and kindred products; apparel and related products; printing, publishing and allied products; and fabricated metal products; these four accounted for $51 \%$ of manufacturing employment in 1976.

Although Philadelphia's air quality has Improved significantly in the last ten years, this region is faced with a severe air quality problem. With respect to the five National Ambient Air Quality Standards, Philadelphia does not meet the primary standards for oxidants or carbon monoxide and the secondary standards for particulates. The city is close to achieving the sulfur dioxide standards and the primary particulate standards. Philadelphia was in compliance with the oxides of nitrogen standard in 1977, but will probably

$\star 1960$ U.S. Census percentages are for blacks, while 1970 percentages are for "non-whites." 
exceed it in 1978. As in most areas on the East Coast, the most difficult to meet will be the oxidant standard, for which peak levels are about twice the standard in the city and three times the standard in suburban locations. It will also be very difficult to maintain the sulfur dioxide and particulate standards once they are attained:

HOUSING

Most of the city's housing, which consists almost entirely of two-story brick rowhouses, is well over 50 years $01 \mathrm{~d}$. To a degree unusual for a large Eastern city, dwellings are predominantly single-family, owner-occupied. Much of the occupied housing is somewhat delapidated and therefore offers potential for improvements in energy efficiency.

In Philadelphia, as in most densely populated metropolitan areas, interviewees saw few opportunities for the construction of new housing. Through a number of municipally administered and federally funded programs, the city is engaged in a variety of efforts directed to housing rehabilitation. Some of these (like the Gift Property program and the Urban Homesteading program) rely heavily on homeowner "sweat equity"; others (like a program through which residential properties are acquired, rehabilitated, and sold) are carried out entirely by the city; and some (like the Loans and Grants program) offer financial assistance to individual homeowners.

Housing improvements or renovation accomplished under all these programs generally include installation of insulation or storm windows, furnace repairs or replacement, and so forth. Substantial energy savings may therefore be expected to accrue. As a number of interviewees were quick to point out, however, these savings are largely incidental to the primary goal of Philadelphia's housing rehabilitation efforts: that of promoting the city's economic development through holding or attracting urban residents. Indeed, potential conflicts between the goals of economic development and of energy conservation in the housing sector in Philadelphia were sometimes noted. It was suggested, for example, that adoption of building codes with stringent building energy efficiency components or -- more to the point in Philadelphia, where relatively little new construction is likely to occur -- adoption of mandatory energy efficiency requirements for all housing* would escalate renovation cósts, which would slow neighborhood rehabilitation and thereby impede urban economic

*A frequently noted example was Portland, Oregon's proposed conservationoriented housing standards. 
development. Furthermore, insofar as the implementation of such standards raises housing costs, it would weigh most heavily on lower income groups.

Aside from a number of essentially educational programs (for example, free home energy audits), Philadelphia's major program aimed directly at promoting energy conservation in the residential sector is the weatherization program. Unlike many of the city's housing rehabilitation programs, described above, which benefit primarily families of middle or moderate. incomes, the weatherization program is aimed exclusively at the lowest income groups.

This program is administered by the Philadelphia Allied Action Commission (PAAC), a municipal anti-poverty agency. The program, which began in March 1976, was extensively and effectively publicized in the sumer of 1977 when many low income families became eligible for property tax rebates: information on the weatherization program was mailed out with the rebate checks. The response was immediate and overwhelming. As of May 1979, 1647 Philadelphia homes had been retrofitted under this program, but the staff still faces a backlog of some 4000 applications.

Eligibility criteria for the Philadelphia program, in addition to the federal income standards (listed previously), currently include the following:

1. The home must be a single-family dwelling. Apartments and storefronts, for example, are not eligible.

?. The home must. he owner-ncrupien. Althnugh, as discussed above, Pennsylvania's Community Energy Office now requires that all local weatherization programs include at least $25 \%$ rental units, the Philadelphia program has received a one-year exemption because of the large backlog of applications.

3. The roof must not leak, and the house in general must be in reasonably good condition. That is, its condition must be such that weatherization, which is limited to caulking, weather stripping, and the installation of ceiling insulation and storm windows, can be reasonably expected to make some difference in fuel requirements.

4. Preference is given to homes owned by the elderly or the handicapped.

According to city officials, the program has focused almost exclusively on the elderly and the handicapped: $>65 \%$ of the total number of homes retrofitted in 1978 had such owners. 
Problems besetting the Philadelphia program are diverse. Officials find that current funding levels provide for only the most inexpensive retrofits, and this could well be resulting in significant economic inefficiencies. Moreover, it eliminates from eligibility many of the neediest households, those living in delapidated or semi-delapidated housing. For example, of the otherwise eligible program applicants in Philadelphia, 10 to 20 percent have to be turned down because their roofs leak, a defect which would soon render retrofitting ineffective. Usually the problem is relatively minor, probably requiring about $\$ 700$ to 900 in repairs. The Philadelphia weatherization program, however, spends an average of $\$ 600$ to 1200 per house and clearly has not the funding (or mandate) for undertaking the necessary roofing repairs.* Indeed, with current levels of funding, PAAC cannot even act with reasonable promptness on its backlog of eligible cases.

\section{INTEGRATED ENERGY SYSTEMS}

Philadelphia has some district heating, supplied to central city buildings including municipal buildings and the University of Pennsylvania campus, via a steam loop from Philadlephia Electric's Schuykill electric generating plant and Edison steam plant. Many other, more ambitious integrated energy systems are envisioned by selected agencies for the city, but they are far from realization. For example:

a. With a view to matching total energy requirements and available technologies, integrated community energy systems are being explored for one of the city's areas targeted for comercial redevelopment.

b. A citywide assessment of industrial, commercial, and institutional ICES applications is to be funded by the Pennsylvania Governor's Energy Council.

c. Philadelphia Electric Company, United Engineers, and the City of Philadelphia are jointly investigating the feasibility of district heating through cogeneration in the city. The study will include evaluation of four potential district heating sites.

As these program descriptions suggest, work related to integrated energy systems for the City of Philadelphia is still in its initial stages. The work

*It is noteworthy that program costs per house completed have undergone a sharp rise since 1978, apparently due entirely to increasing operating costs. 
has focused on the economic and technical aspects of these systems, with little or no attention to social and environmental effects; however, such effects will have to be considered as integrated energy systems are developed and adopted. Possible social problems, benefits, and constraints are related primarily to the settlement pattern changes implicit particularly in many ICES concepts. These are discussed below in the section on land use patterns.

Some major environmental issues related to the development of integrated energy systems in Philadelphia are being investigated. An ICES is being considered for a large shopping mall to be located within the central city, and its impact on air quality is an environmental issue of local concern. The ICES unit will probably be gas-fired and will thus increase the nitrogen oxide level nearby. A utility credit would of course be provided, but it is not clear that this would benefit the air quality within the city as a whole. Expansion of the present district heating service area is also being considered, with the heat being provided by retrofit of existing power plants near the heat demand centers. Air quality concerns have not been addressed, but the impacts are expected to be beneficiai. With respect to industrial cogeneration, a large potential also exists because of the process heat demands of industry within the city. Certain respondents said that environmental issues do not appear to be limiting additional penetration of this technology.

\section{LAND USE PATTERNS}

Concentrated settlement patterns are implicit in the district heating and especially in the integrated community energy systems concepts. However, settlement concentraton is in conflict with the land use trends prevailing in the Philadelphia area for many years -- trends toward increasing suburban sprawl and scattered, leapfrog growth. The Delaware Valley Regional Planning Commission 6 has provided a vivid description of this growth process:

\footnotetext{
"The pattern is characterized by (1) the formation of sprawling fingers of urban use along the main transportation corridors and connecting rural roads, (2) the expansion of the urban area into its rural hinterland and corrresponding disappearance of the rural character of the land, (3) the thinning out of urban uses as development spread outwards, both by a less intense use of land and by a greater spacing between uses with large empty spaces in-between, and (4) the relative growth of commercial and industrial land uses in the suburbs at the expense of the dominant city of the region, Philadelphia, and the other smaller cities, Trenton, Camden, Chester and other old towns."
}

The Delaware Valley Regional Planning Commission, encompassing the ninecounty Philadelphia and Trenton Standard Metropolitan Statistical Areas, advo- 
cates cluster rather than scatter development and seeks to limit strip development, preserve open space, and concentrate growth in urban fringe areas, vacant parcels in developed areas (infill), and urban redevelopment. The commission is a planning and advisory body, and the ultimate success of its 1 and use planning strategies depends on the force of its supporting arguments.

Many of Philadelphia's major energy problems are closely related to recent settlement and growth patterns characterized by the detached singlefamily dwelling and predicated on the commuter automobile, both with very high fuel requirements. Patterns requiring less automobile use and less costly physical infrastructure would provide significant environmental and economic, as well as energy, benefits. There are, however, numerous obstacles to the success of regional land use planning in the Philadelpha area. Those most often mentioned include the following:

a. Concentration of growth in the urban areas or fringes conflicts with the aspirations of many suburban areas toward continued economic development.

b. Current land use patterns represent a vast public and private financial investment and are therefore not likely to be abandoned soon or easily.

c. Perhaps of greatest significance, people have a considerable emotional and psychological investment in contemporary land use patterns.

This last and most intangible obstacle is notably intractable to the policy planning process. One interviewee noted that the problem is not, or should not be, one of changing people's attitudes but rather one of finding novel solutions that will satisfy in a new way both the goals and objectives of the regional planner and the perceived needs and desires of individual citizens.

\section{TRANSPORTATION}

Transportation is an important component of land use planning, for transportation patterns and modes both shape and are shaped by patterns and rates of population mobility, access to services, and community settlement patterns. However, transportation, especially as it relates to energy use and conservation, entails distinct kinds of problems and considerations and is therefore best treated separately from the general issue of energy impacts of land use patterns.

Urban transportation is perhaps the greatest consumer of energy. Not only do automobiles consume huge quantities of gasoline, but also they discharge atmospheric pollutants formed during combustion. Any reduction in gasoline use would favorably affect air quality. 
Because of air quality problems within the city of Philadelphia related to energy use in the transportation sector, two basic approaches are being used to conserve gasoline and thus improve air quality: reducing kilometers of travel by automobiles and increasing use of mass transit, which is usually considered to be more energy-efficient. Philadelphia has a highly developed mass transportation system consisting of buses, surface trolleys, subways, and commuter railways. At present, 50 to $75 \%$ of all passenger miles within the city are traveled via these modes, and the system is operating at near capacity. The lines could handle some increse in capacity, but the availability of rolling stock plus adequate safety controls on this older subway system would limit additional expansion without major renovation.

Several environmental considerations arise in assessing the effects of increasing ridership via mass transit. More diesel buses, for example, on the street may increase levels of air pollutants, especially particulates. The use of high-speed transit, such as commuter rail and light rail, would not only change the type of fuel used but also cause fuel to be burned at fixed points where energy conversion would take place; therefore, the effects of increased emissons at those points need to be studied.

of greatest concern to many officials and individuals are mechanisms for reducing private automobile use because of their large effect on air quality. Strategies employed or under consideration in Philadelphia include the following:

Introduce car, van, and bus pools and other shared-ride programs. Revamp working hours (staggered work hours, flextime, etc.) Provide public parking facilities at interfacing points with public transit systems.

Introduce incentives to use public transportation for individuals in areas with critical air quality or traffic density problems.

Examine and recommend entry and exit points to improve traffic flow.

All these measures would decrease air pollutant emissions roughly in proportion to the amount of fuel saved. In areas with critical air quality problems due to transportation sector emissions, benefits may be magnified. Increased use of small cars and diesels could reduce energy use but would not significantly improve air quality. The federal emissions standards for lightduty vehicles are linked to vehicle miles traveled, not miles per gallon. Thus, decreasing gasoline use does not affect end use emissions although it 
may reduce supply sector emissions. Furthermore, some argued that shifting drivers to smaller cars may actually increase vehicle miles traveled, which would have negative environmental and health impacts.

\section{UTILITY RATES}

Utility service in Philadelphia is provided by the Philadelphia Gas Works and the Philadelphia Electric Company. Both use a residential rate structure of the traditional declining block form (albeit declining but slightly), which critics claim promotes the wasteful use of energy and allots an unduly large share of the cost to low-income, small-user customers. Both PECo and PGW, nowever, offer a number of innovative rates that discourage energy use, curtail peak demand, or partially offset rising utility bills for selected categories of customers. For example:

a. PECo offers demand-metered rates to its general-service primarydistribution power and high-tension power customers, and it has filed with the Pennsylvania PUC for an experimental demand rate for 360 residential service customers to explore price elasticities of peak demands.

b. PECo and all other electric utilities in Pennsylvania with sumer peaking conditions have seasonal peak pricing.

c. PECO offers off-peak service in the form of controlled water heating tariffs, which is utilized by $92 \%$ of all residential electric water heaters in its service territory.

d. PECo has proposed an off-peak residential rate, identical to its controlled water heating rate, which permits customers to hardwire any electric appliance to an off-peak controlled circuit.

e. PGW offers a seasonal service rate to industrial, commercial, and residential buildings.

f. PGW offers a senior citizen discount of $20 \%$ to customers over 65 .

Both utilities, however, are opposed to inverting the declining block rate structure, which, its proponents argue, could have significant positive impacts for both conservation and social welfare. Both PECo and PGW have sponsored studies of life-line rates, a form of inverted block pricing explicitly aimed at shifting some of the burden of rising utility bills from the poor and presumably low-level energy users to the wealthier and larger users. These studies, using income, energy use, and other selected characteristics of Philadelphia area customers, offer a variety of arguments against life-line rates and, by implication, against inverted block pricing. The major 
arguments are that such rates might encourage increased energy use among low volume users, and, because no direct correlation was found between income and energy use, that they would adversely affect many low income customers while benefitting many middle and upper income families.

Some of the income and energy use statistics used in the PGW and PECo studies are problematic, but a number of other arguments against life-line rates and inverted block pricing have also been put forward both by these utilities and by the Pennsylvania PUC. 5 The most prominent of these arguments are that rate structures should be based upon cost of service (which inverted block structures generally are not), and that social welfare concerns should properly be addressed by welfare agencies rather than by utilities.

\section{ERIE}

Erie County is located in the northwestern corner of Pennsylvania. Its area is 813 square miles and its 1975 population was 273,396 or 336 persons per square mi le. The city of Erie, county seat of Erie County and third largest city in Pennsylvania, is on the southeastern shore of Lake Erie about 100 miles east of Cleveland and 90 miles south of Buffalo. Its area is 18.9 square miles and its 1975 population was 127,895 (47\% of the county), or 6767 persons per square mile.

From 1960 to 1970 , the population of the city of Erie decreased by $6.7 \%$ (from 138,440 to 129,220 ). While the total county population increased hy $5.2 \%$; much of this is probably attributable to population movement from city to suburbs.

Although the city of Erie has only $47 \%$ of the total county population, it has larger proportions of the dependent and low income groups than the remainder of the county, especially blacks, $96 \%$ of whom reside in the city.

Erie is a major manufacturing area. According to the 1979 Pennsylvania County Industry Report for Erie County, in 1976 it had 486 manufacturing industries and ranked eighth among the State's counties in industrial employment $(41,665$ employees) and eleventh in value of production $(\$ 2,033,344.000)$. The county's 1970 employment total was 98,772 of whom $41 \%$ were employed in manufacturing, mostly of durable goods. The county's four leading industrial employers are a General Electric plant, manufacturing chiefly locomotives and transit cars (emp. 11,200); Zurn Industries, manufacturing air, water, and thermal control systems and components (emp. 4000); a Hammermill Paper plant 
(emp. 1948); and the American Sterilizer Company, manufacturers of hospital equipment (emp. 1500). A large U.S. Steel plant (the Conneaut plant) has been proposed for a 2,760 acre site straddiing the Ohio/Pennsylvania border on the western edge of Erie County. According to U.S. Steel's Final Environmental Impact Statement for the plant, it is expected to employ 8500 permanent workers when completed.

As in the city of Philadelphia, air quality has improved in Erie in the last decade, but some severe problems remain. With respect to the five National Ambient Air Quality Standards, the city is in noncompliance for ozone and particulates. Source emission estimates similar to those prepared for the city of Philadelphia are not available.

HOUSING

Erie County housing stock is composed predominantly of owner occupied, single-family, gas heated dwellings built prior to 1939 and valued at around $\$ 14,500$.

The city of Erie and the surrounding county (i.e., the balance of Erie County excluding the city of Erie) differ in several respects:

a. Far larger proportions of county homes than of city homes are owner occupied ( $78 \%$ vs. $60 \%)$.

b. Similarly, larger proportions of county homes than of city homes are single-family dwellings ( $89 \%$ vs. $60 \%$ ).

c. The median value of county homes is higher than that of city homes $(\$ 15,900$ vs, $\$ 13,400)$.

d. County homes on the average are newer than city homes (23\% vs. $6.8 \%$ built after 1959).

Within the county and the city of Erie, as yet, few formally organized programs or efforts are directed toward increasing the energy efficiency of housing. Local building codes, for example, do not include energy performance standards, and there are no plans to add such standards in the near future. Although local community development and housing assistance programs include energy conserving housing renovations, these efforts are confined to selected neighborhood strategy areas, and energy efficiency improvements are only incidental to overall community development goals.

Erie's two weatherization programs are the major exceptions to a predominantly laissez-faire approach to improving energy efficiency in the housing 
sector. The county weatherization program, administered by the Redevelopment Authority of the County of Erie, was started in 1975 and covered the whole county until 1978, when a separate weatherization program, administered by the Greater Erie Community Action Committee, was organized for the city of Erie. Program efforts are directed toward conserving energy and reducing its costs for the poor through improving the energy efficiency of their homes. From client responses to a questionnaire, the Redevelopment Authority estimated that the programs' weatherization improvements have brought about fuel bill reductions of $10 \%$. (Note that this figure probably understates fuel savings because of rapidly rising fuel costs.)

Interviewees identified several major problems facing the Erie area weatherization programs:

1. Application rates. Although interviewees generally characterized both the city and county of Erie as having large numbers of low income families and substandard dwellings, both weatherization programs (particularly the county program) have met with lower than expected application rates. This problem is said to be due to an ethic of "not wanting to take charity."

2. The new requirement that all Pennsylvania weatherization programs include at least $25 \%$ rental units. Meeting the state and federally set $25 \%$ requirement might be difficult. A more important problem is that inclusion of rental units may require disproportionate amounts of funds to overcome several major hurdles, the foremost being the prevalent style of 1 andiord-tenant relations. On the other hand, the estimate that among blacks the percentage of families residing in rental units is $80 \%$, if accurate, suggests that weatherization programs in the Erie area and possibly in other areas may have been systematically, albeit inadvertently, discriminating against blacks in excluding renters from the programs; and the new $25 \%$ renter requirements may help to rectify this situation.

3. Excessively delapidated homes. It is estimated that $20 \%$ of applicant homes require major structural renovation in order for weatherization improvements (insulation, caulking, storm windows) to be at all effective. Both programs seek to coordinate their efforts with those of local community development and housing rehabilitation programs so that homes can be brought up to "weatherization standards," but many otherwise qualified applicants still have to be rejected because of the poor condition of their homes. 
Interviewees suggested that weatherization efforts could be more effective if the programs included provisions for housing rehabilitation.

\section{INTEGRATED ENERGY SYSTEMS}

In Erie, integrated energy systems are confined to industrial and commercial applications. There is at present one industrial cogenerator in the area: the Hammermill Paper Plant generates its own electricity and sells its excess to the Pennsylvania Electric Co. (Penelec, the electric utility serving Erie) on a split-cost basis. Penelec pays one-half the difference between Hammermill's production costs and the value of the electricity to the Penelec system, but its officials note that this contract is not as lucrative to Hammermi 11 as current Federal Energy Regulatory Commission (FERC) guidelines suggest. The General Electric plant, Erie's largest employer, also generates its own electricity, and it sold power to Penelec in the 1960s; but its own requirements have increased dramatically, and it now buys addditional power from Penelec.

Parts of downtown Erie are served by a district heating system which is supplied with steam from Penelec's Front Street Station in the city of Erie. This station, the only power plant in the county, is a coal burning facility with a generating capacity of $118,800 \mathrm{~kW}$, and its steam loop supplies heat to 231 municipal and commercial customers in Erie.

Interviewees unanimously entertained little prospect for the growth of integrated energy systems in the Erie area in the near future. Penelec, in fact, would like to phase out its district heating service. This utility formerly had district heating systems in many parts of its territory, but most of the small urban power plants that supplied the steam for these systems have been abandoned and replaced by large facilities located in outlying, sparsely populated areas. The Erie system, the only district heating system remaining in the Penelec service territory, is old and is expensive to maintain. According to some interviewees, it is also unreliable; and many steam customers have gas-fired backup heating systems.

LAND USE

Energy considerations currently do not play a significant role in land use planning in the Erie area. In Erie County, $42 \%$ of the land is agricultura1, and the rest appears and is reported to feature a preponderance of single-family residential zoning, largely unplanned suburban sprawl, and strip 
development. Recent comercial development in outlying areas, notably a large new suburban shopping mall which does not use an ICES but buys electricity from Penelec -- both reflects and stimulates these trends.

Interviewees suggested that recent gasoline shortages had brought about a growing awareness of the link between some aspects of land use patterns and energy requirements. But, they also suggested that the financial and emotional investment in single-family property and in a suburban or small town atmosphere was likely to impede any translation of this new awareness into an alteration in land use trends. On the other hand, local business interests indicated that economic changes associated with recent energy shortages may soon limit some kinds of suburban spread. To illustrate, construction of the large mall mentioned above was premised on a large and geographically farflung market. The recent gas shortage, however, caused a dramatic decline in sales as people come less frequently from the rural and semi-rural hinterlands into the Erie area to vacation and shop, and as Erie area residents do more of their shopping in their more immediate neighborhoods. To paraphase one interviewee, "If we had known gas was going to cost over a dollar a gallon, we never would have considered building the mall."

TRANSPORTATION

Quantitative data on energy use by private automobiles versus mass transit systems are not available for the city or county of Erie, but the area is much more dependent on the private automobile for transportation needs than is the city of Philadelphia because of its semi-urban nature and the needs of residents who commute many miles between home and work. Although transit buses are available, and some run between the city and several of the large industries located at its edge, mass transit opportunities have yet to be fully exploited. Because of the sprawling settlement patterns, mass transit costs would far exceed those of Philadelphia or other densely settled areas. In any case, the expected impacts on air quality within the city or country are expected to be marginal. Ozone, although related to automobile transport, is a regional problem and must be dealt with as such. In Erie, particulate problems are related to industrial sources.

\section{UTILITY RATES}

Erie is served by the National Fuel Gas Company (NFG) and the Pennsylvania. Electric Company (Penelec). 
NFG supplies gas to 472 communities throughout western. New York and northwest Pennsylvania. Of its 200,000 customers in Pennsylvania, $90 \%$ are residential, and almost all of these use gas for heating, but the residential share of total company sales is $<50 \%$. NFG rates in the Pennsylvania portion of its service territory are of the traditional declining block form. The company does not provide special discount, life-line, or seasonal rates to residential customers but does offer low interest loans for home insulation.

Penelec, controlled by General Public Utilities Corporation, supplies electricity to 31 counties in a predominantly rural 17,600 square mile area in the northern tier and west central parts of Pennsylvania. It has 490,000 customers, of whom $90 \%$ are residential, but only $30 \%$ of its total electric generation goes to residential use, the remainder going to industrial (40\%) and commercial (30\%) uses. Penelec rates for all customer classes are of the moderately declining block form. The company has initiated a conservation and load management program and offers a number of innovative rates to various classes of customers throughout its territory:

a. Curtailment rate schedules are available to customers having at least $1 \mathrm{MW}$ of curtailable load.

b. An off-peak provision is available to large customers, those with demands of 50 to $3000 \mathrm{~kW}$.

c. An off-peak water heating tariff is available to Penelec's small general service customers.

d. Residential customers installing approved antomatic storage water heaters may take advantage of a special rate schedule, but they grant Penelec the right to install time control devices at the company's discretion.

In addition, Penelec has recently introduced experimental time-of-day rates for residential customers, but it estimates that customers would have to shift 60 to $70 \%$ of their loads to off-peak hours to realize any savings under these rates. In Penelec's view, a shift of this magnitude is probably feasible only for residential heating or water heating customers able to make a major investment in heat storage equipment. Hence, although $8 \%$ of Penelec's residential customers use electric heat and $22 \%$ have electric water heating, only 35 customers are now billed under time-of-day rates.

It is readily apparent from the list above that Penelec's conservationoriented rate measures focus on load management rather than curtailment of use. Rate alternatives encouraging reduced use -- such as certain forms of 
marginal cost pricing and inverted block pricing -- are under study but are not being seriously considered for implementation in the near future.

With regard to social welfare concerns related to rapidly rising utility bills, Penelec favors an energy stamp scheme over any form of life-line rates, arguing that life-line rates are not easily targeted to those customers in need of assistance. A number of consumer, union, and environmentalist groups in the Erie area, however, contend that energy stamps could constitute a taxpayer-financed subsidy to the utilities, and they instead advocate and are actively campaigning for public ownership of both Erie utilities.

\section{REFERFNCFS}

1. P. D. Moskowitz, T. Q. Le, and B. L. Pierce, Ranking Energy Conservatiun Measures to Establish Research Priorities: Synopsis of a Workshop, NCAES, BNL 51046, May 1979.

2. P. D. Moskowtiz et al., Energy-Environmental Impacts of Five Energy Conservation Strategies in the Middle Atlantic and Pacific States, NCAES, BNL 51110, Oct. 1979.

3. Weatherization for Renters: A Discussion of the Issues and Policy for Pennsylvania, Dept. of Community Energy, Harrisburg, Jan. 4, 1979. Page 2 quotes from "Report to the Congress: Complications in Implementing Home Weatherization Programs for the Poor."

4. Ibid. Page 2 quotes from A. Levy, "Weatherization of Rental Units."

5. M. P. Bloom, R. A. Rosenthal, and W. F. Japak, Generic Rate Structure Investigation, Final Report, Penn. PUC, Dec. 1977.

6. Year 2000, Land Use and Open Space Plan, p. 40, Delaware Valley Regional Planning Commission, Draft, Jan. 1979.

7. J. E. Hass, R. H. Smiley, and R. T. Curtis, Evaluation of Alternative Rate Structures for Philadelphia Gas Works, p. 39, Unpublished, Sept. T978.

8. J. S. Munson and R. Stern, Regional Energy-Environment Data Book: Northeast Region, NCAES, BNL 24867 , Oct. 1978. 


\section{APPENDIX A}

\section{INTERVIEWS}

In each of the three communities visited, interviews were arranged with representatives from a variety of functional areas: they had responsibility for energy policy analysis within their respective groups or organizations. Since anonymity was promised to each of the interviewees, names and specific agencies are not listed; only the functional areas are shown.

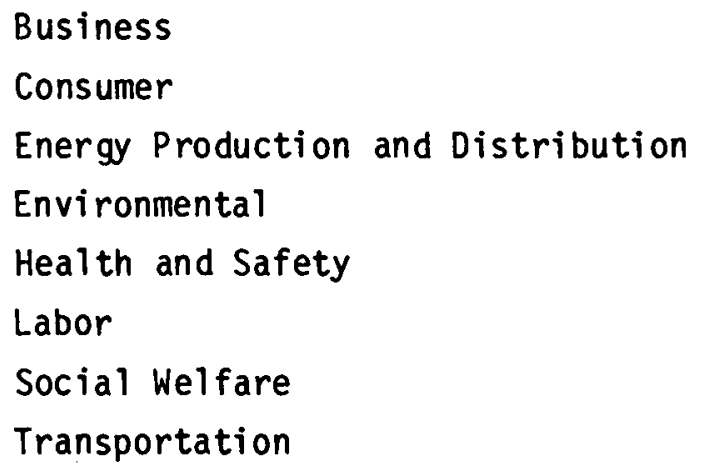

In Harrisburg, five interviews were conducted with twenty persons; in Erie, eight interviews with sixteen persons; and in Philadelphia, seven interviews with nineteen persons. 
APPENDIX B

LETTER AND ENCLOSURES. SENT TO INTERVIEWEES

III

BROOKHAVEN NATIONAL LABORATORY

ASSOCIATED UNIVERSITIES. INC.

National Center for Anaiysis of Energy Systems

Upton. New York 11973

(516) 345-

August 10, 1979

Mr./ins: J. Smith

United Agencies and Enterprises

00 Main Street

Philadelpha, Pennsylvania 00000

Dear Mr./Ms. Snith:

At the request of the Assistant Secretary for Environment in the U. $S$. Department of Energy, Brookhaven National Laboratory is conducting a study to identify significant environmental, health and safety, and social welfare concerns presently or potentially associated with energy conservation measures and strategies. Resulits of this work will be used to help (1) define needs and priorities for environmental, healtin; and social research related to energy conservation, (2) develop an information base to assist the Department of Energy in the preparation of planning documents, environmental impact appraisals, and Congressional testimony, and (3) ultimately guide the development of U. S. energy policies by providing information and perspectives on the relative environmental and social benefits and costs of al ternative energy conservation measures.

We are attempting to identify and assess issues and concerns related to energy conservation by conducting a series of interviews with individuals in government and the private sector who are concerned with energy use and its possible costs and benefits. In the course of each interview, we will explore each interviewee's concerns and expectations about the potential impacts of energy conservation in general and mora specifically as they relate to a set of energy conservation strategies of particular interest to the Department of Energy. Brief technical descriptions of these strategies are enclosed (see Attachment I). Al so enclosed (Attachment II) is a brief descriptive list of a number of facets of the social and environmental setting which could affect or be affected by energy conservation and which, therefore, may be of concern to interviewees.

The conservation strategies and the social and environmental topics covered in these attachments, however, are not intended as an agenda for discussion. We realize that interviowees will be more familiar with some areas than with others, and would hope to focus on those subjects and issues which are of particular concern to participants. The interviews will, therefore, not follow a rigid fonmat, but will be relatively free-flowing in order to encourage participants to share their thoughts on diverse topics--including, no doubt, many that we have not 
anticipated or with which we are not familiar. Throughout, interviewees will be particularly encouraged to draw upon their professional and community experiences, knowledge, and background in discussing and evaluating energy conservation.

Pursuant to our telephone conversation, we $\mathrm{plan}$ to meet with you and other interested members of your firm at your office on Tuesday, August 21, at 3:30 PM. Should you wish to change these arrangements, please call us at (516) 345-2045 (Carlene) or 345-2017 (Paul). We look forward to talking with you.

Sincerely,

PauT D. Moskowitz Project Manager

Carlene Bryant Consultant

PDPi/CB/miw

enclosure 


\section{ATTACHMENT I \\ CRITICAL ENERGY CONSERVATION MEASURES}

\section{Retrofitting Existing Buildings}

Almost $20 \%$ of all the energy consumed in the United States is used to heat and cool residential and commercial buildings. Most of these buildings are not adequately insulated, and many waste as much energy as they actually use. In recent years there has been a trend toward constructing buildings with better thermal qualities, but a large proportion of all existing buildings could benefit from increased insulation and weatherization. These techniques include caulking and weatherstripping around doors and windows, adding insulation to attics, ceilings, walls, and floors, installing storm windows and doors, insulating hot water heaters and heating and cooling ducts, installing clock thermostats, modifying heating and cooling systems, and employing energy load management procedures. Many of these techniques are relatively inexpensive, and can be applied to most kinds of buildings, including single-family houses, multi-family dwellings, mobile homes, stores, office buildings, schools, hospitals, and light industrial buildings. A national program to lmprove the energy efficiency of existing buildings through such retrofit techniques could reduce our annual national energy consumption by 2 quadrillion Btus (or "quads) by 1985 - which is about $3 \%$ of our current consumption. And by the year 2000 this energy saving could rise to over 10 quads.

\section{District Heating and Integrated Community Energy Systems (ICES)}

In a district heating system, a single heating unit serves an entire neighborhood or other clusters of buildings. Water is heated at $165^{\circ}-300^{\circ} \mathrm{F}$ in a central furnace, and then distributed to all the buildings through a network of buried pipes. Within each bullding a heat exchanger produces space heating (or low-level process heat for industrial purposes), after which the water is used directly as hot water. Although it is quite popular in Europe, district heating has not been extensively implemented in the U.S., even though the cost of installing these systems is about the same per building as installing separate furnaces and hot water heaters. ICES is more complex than district heating, since it provides heating, air conditioning, electricity, hot water, and liquid and waste disposal through a single, on-site integrated system. The system might involve any of several technologies, including ofl, gas, coal-f1red burners and generators, solar energy devices, heat pumps, solid waste incinerators, and biological treatment of liquid wastes. In all cases, the goal is to use energy and other resources in multiple, integrated ways to achieve maximum efficiency. Potential sites for ICES include small towns, urban renewal projects, new housing developments, military bases, downtown business districts, commerctal and industrial complexes, government complexes, university campuses, and similar settings. The initial cost of an ICES 1s higher than for district heating, but its overall cost efficiency can be much greater. It has been estimated that these two procedures could together reduce our national energy consumption by approximately 6 quads -- or $8 \%$ of our current consumption -- by the year 2000 .

3. Small Automobiles and Vehicle Redesign

Gasoline for automobiles accounts for roughly $13 \%$ of all energy consumed in the U.S. today, and an additional large amount of energy is required to produce the steel and other materials that are used in cars. Small cars (weighing under 3000 pounds) consume much less energy than larger cars because, (1) they get much greater gasoline mileage (due to less welght, fewer power options, and reduced aerodynamic drag), and (2) require less energy to manufacture. The Energy Policy 
and Conservation Act of 1975 requires that the average fuel efficiency of each manufacturer's new car fleet must be $19 \mathrm{~m} \bullet \mathrm{p} . \mathrm{g}$. for 1979 cars and must rise to 27.5 m.p.g. for 1985 cars. Several other steps could also be taken to encourage people to purchase small cars including imposing exclse taxes on all large cars, giving rebates on the price of small cars, or prohibiting the manufacture of cars over a specified weight limit. Automobile manufacturers, meanwhile, could be encouraged to make numerous design changes in cars to increase their fuel efficiency, including producing more diesel engines, introducing other types of efficient engines, reducing internal friction, improving carburetion, lowering aerodynamic drag, replacing steel with aluminum and other lightweight materials, and putting radial tires on all new cars. The current EPCA requirements are expected to reduce our national energy consumption by approximately 3.7 quads -- or $5 \%$ of our current consumption -- by 1985, and save 7 quads per year by the year 2000 .

4. Land Use and Housing Modifications

The amount of energy consumed in a community is heavily influenced by numerous features of 1 ts land-use patterns and housing stock. Particularly crucial in the United States have been our pervasive urban trends toward single-family dwellings, suburbanization and urban sprawl, separation of work and residences, and land development patterns that prohibit efficient mass transit systems. Comprehensive community design and development to provide more energy-conserving land use, housing types and locations, and transportation networks would result in substantial energy savings. Such changes could be accomplished through the use of such procedures as overall community planning, zoning and bullding requirements, public ordinances, and other legal tools. The goals of these efforts might include constructing more multi-family dwelling units, redeveloping inner-city areas, locating industries in "industrial parks" with nearby housing for workers, introducing new forms of mass transportation such as "people movers", and organizing cities into "nelghborhood clusters" containing all necessary facilities and services within easy walking distance. The cumulative effects of such actions could potentially reduce our national energy consumption by 10 to 18 quads -- or 15 to $25 \%$ of current consumption -- by the year 2000 .

5. Electric Utility Rate Reform and Load Management

Most electric utilities charge their customers on a "declining block rate" structure. Three main features of this rate structure are that: the more electricity one uses, the lower the cost per kflowatt hour; electricity used during "peak" periods of heavy demand costs no more than electricity used at other times; and the cost of electricity produced by more expensive generating facilities (such as nuclear plants) is averaged in with the the cost of electricity from less expensive facilities (such as hydroelectric plants). As a result, (a) there is a financial incentive to consume rather than conserve electricity, since the smallest users pay the highest unit prices, (b) there is no incentive to reduce electricity consumption during peak hours or seasons, so that utflities must maintain costly (and often inefficient) standby generating facilities to meet peak demands, which further increases the cost of electricity, and (c) as plant construction and fuel prices continue to rise, customers are not charged the full marginal costs of adding new generating capacity and supplying additional electricity, which encourages increased consumption. The Public Utility Regulatory Policles Act of 1978 requires state regulatory authorities and utilities to consider various rate design reforms such as time-of-day rates, seasonal rates, interruptible rates, elimination of declining block rates, and marginal-cost pricing. Implementation of such rate and load management reforms could potentially reduce our national energy consumption by over half a quad - $1 \%$ of current consumption -- by 1985 . 


\section{ATTACHMENT}

Aspects of the Social and Environmental Setting

1. Natural resources - air and water quality, aesthetics, agricultural resources.

2. Land use patterns -- zoning restrictions; patterning, nature, and ava1lability of recreational facilities; typical distannes between home and work, atc.

3. Health and safety - occupational safety, physical and mental. diseases, arrident rạtess, disasters, etc.

4. Employment and the local economy - layoffs, chronic unemployment, new employment opportunities, profits, growth, inflation, changing product demands, personal consumption patterns, etc.

5. Local utilities -- technical operation, economic viability, etc.

6. Individual privacy and freedom - freedom of choice, extent of individual or local control vs. state or federal control, restrictions on activities, etc.

7. Housing -- avallability, cholces, location, quality, price, etc.

8. Transportation -- avallability, adequacy, congestion, price, etr.

9. Local government -- land, capabilities, and resources pertaining to housing, land use, transportation, public servlces, etc.

10. Social and economic equity -- distribution of costs and benefits across economic and social groups. 


\section{APPENDIX C \\ REGIONAL, STATE, AND LOCAL ENERGY PERSPECTIVES}

THE NORTHEAST

In 1975, the Northeast consumed $13608 \times 10^{12}$ Btu of energy. Figure 1 shows energy flows by fuel type and activity within the region. The dominant fuel consumed is 011 ; it accounts for $61.1 \%$ of the total energy used. Natural gas and coal are the next largest sources of raw energy, accounting for 15 and $17 \%$ respectively. Hydropower $(3 \%)$ and nuclear energy $(4 \%)$ meet the remaining deficit.

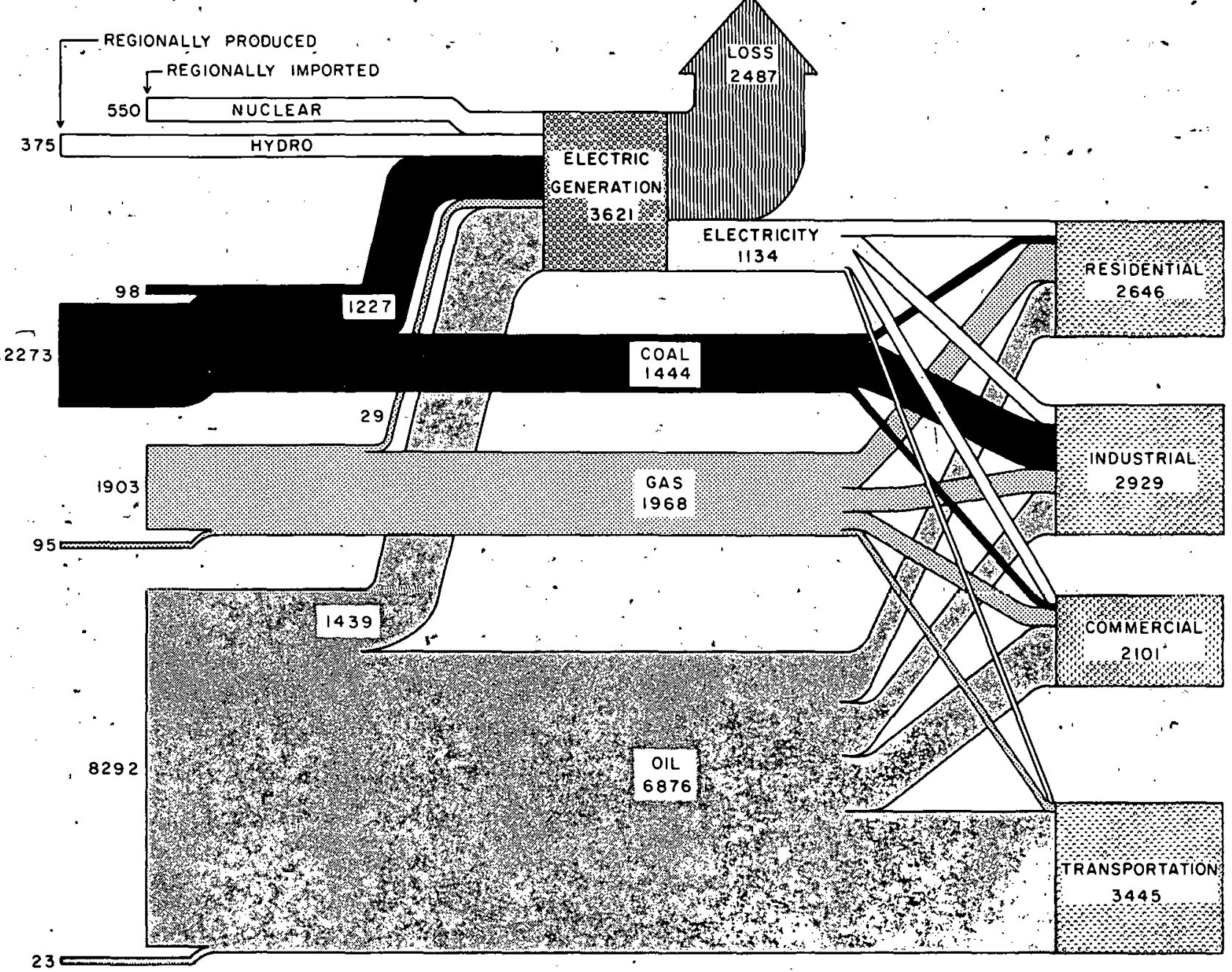

Figure 1. 1975 Northeast Region energy balance: production and consumption. (From Munson and Stern. 8 ) 
of all the fuels supplied, $27 \%$ is consumed in electricity generating plants, and the remaining $73 \%$ supplies non-utility end-use demands. The amounts of fuels consumed for electricity generation differ somewhat from the overall regional pattern but still reflect the regional dependence on oil: $011,39.7 \%$; coal, 33.9\%; nuclear, 15.2\%; hydropower, 10.4\%; natural gas, 0.8\%.

The region's largest energy consumer is the transportation sector $(30.9 \%)$, followed by the industrial (26.3\%), residential $(23.8 \%)$, and commercial $(18.9 \%)$ sectors. In the residential and commercial sectors, space heating accounts for $73 \%$ of the energy used and water heating for another $17 \%$. In the transportation sector, personal automobiles and trucks represent $67 \%$ of the fuel demand, whereas urban and intercity rail and mass transit account for <?\%; the remainder is apportioned to trucks and $p l a n e s$. In the industrial sector, fuel is used primarily for process heat needs and petrochemical feedstocks.

PENNSYLVANIA

In the Northeast, Pennsylvania is the state consuming the most energy; in 1975, it consumed $4000 \times 1012 \mathrm{Btu}, 30 \%$ of the total used in the region. Figure 2 shows the energy flows within the state by fuel type and activity. Pennsylvania differs from the region principally in that the percentage use of petroleum is lower and that of coal is higher, but it still obtains $44 \%$ of its energy from petroleum and is vulnerable to critical shortages of both oil and natural gas.

of al1. the fuels supplied, $29 \%$ is consumed in electricity generating plants; $81 \%$ of this is coal. The largest energy consumer within the state, unlike that in the region, is the industrial sector $(43 \%)$, followed by the transportation (26\%), residential (19\%), and commercial (12\%) sectors. The energy end-use patterns are similar to those of the region. It is critical to note, however, that $75 \%$ of the state's residential and commercial heating requirements are supplied by petroleum. In the industrial sector, $>50 \%$ of the energy used is derived from coal, the rest being equally divided between natural gas and oil. 


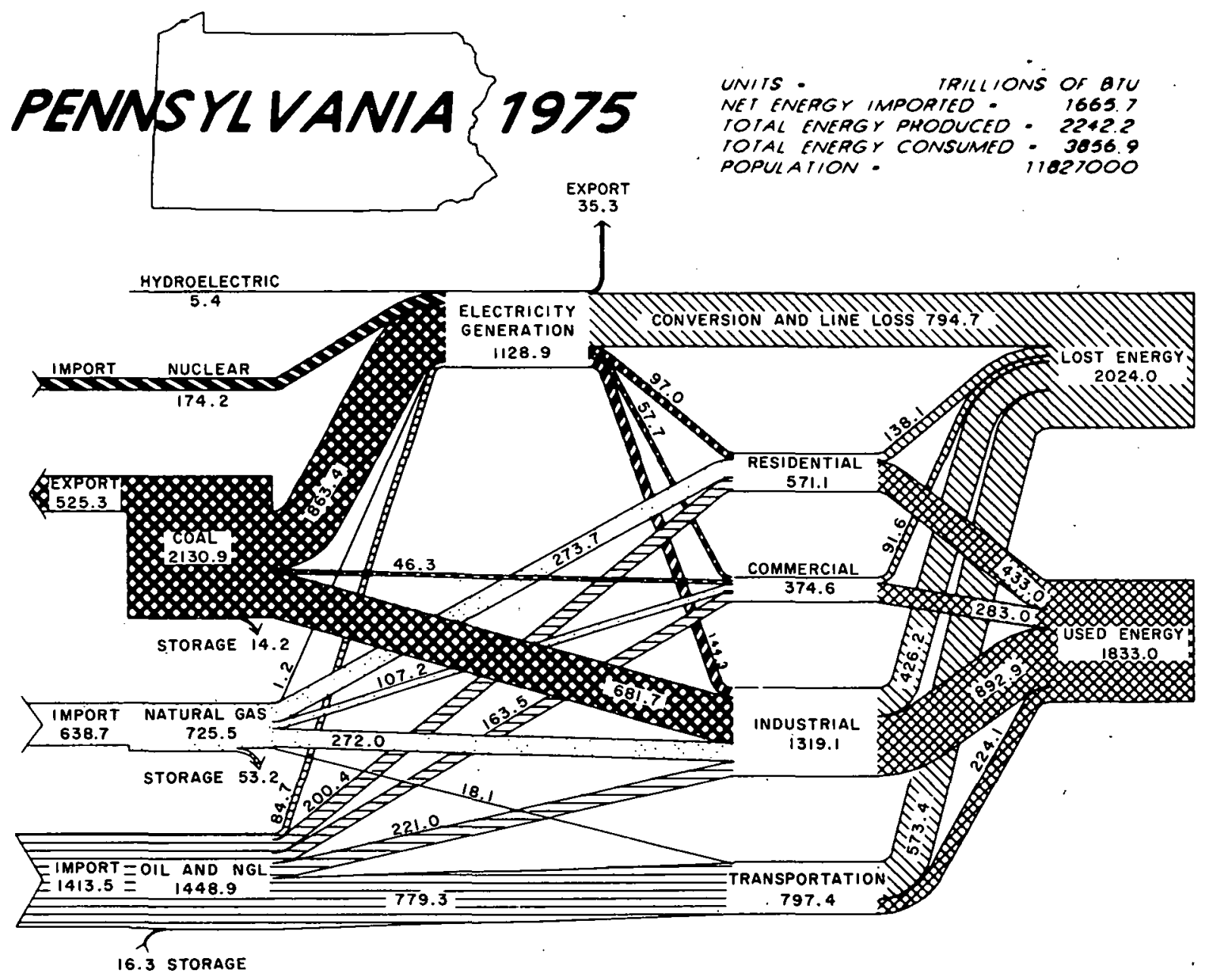

Figure 2. 1975 Pennsyivania State energy balance: production and consumption: (From Munson and Stern.8)

\section{PHILADELPHIA AND ERIE*}

In 1970, Philadelphia County consumed $14 \%$ of all the energy used in the state. The consumption was $45 \times 10^{12} \mathrm{Btu}$ of coal $(9 \%), 30 \times 10^{13} \mathrm{Btu}$ of petroleum (59\%), $14 \times 10^{13}$ Btu of natural gas (26\%), and $48 \times 10^{12}$ Btu of coke (9\%), mostly in non-utility end uses. These county level data reflect both the state and regional dependence on petroleum. of the petroleum consumed, $80 \times 10^{12}$ Btu

*Energy use data by fuel type and demand sector at the local level are difficult if not impossible to obtain. In lieu of such data, we describe overall fuel use by fuel type at the county level. Also presented are fuels used for electricity generation within the county. Data disaggregating end-use demands by fuel type or activity are not available. 
(27\%) was used for transportation, principally by private automobiles. Breakdowns for the remaining sectors by fuel type and activity are not available.

Erie County in 1970 consumed $74 \times 10^{12}$ Btu energy, or $2 \%$ of the total used in the state. This comprised $16 \times 10^{12}$ Btu of coal (22\% of the county total), $34 \times 10^{12}$ Btu of petroleum $(46 \%), 19 \times 10^{12}$ Btu of natural gas $(26 \%)$, and $7 \times 10^{12}$ Btu of coking coal (10\%). Of the coal consumed, $50 \%$ percent was used for central station electricity generation. The transportation sector was responsible for $50 \%$ of the petroleum demand. The county's energy use patterns resemble those of Philadelphia Co. and the state in that Erie Co. is critically dependent upön petroleum fuel sources. Her capita use of energy in trie lo. $\left(280 \times 10^{6} \mathrm{Btu}\right)$ is greater than in Philadelphia Co. $\left(264 \times 10^{6} \mathrm{Btu}\right)$. Erie's greater dependence on coal is related to its heavy industries, including a large number of foundries. Higher gasoline usage is probably related to the semi-suburban nature of the area and the consequent dependence on the private automobile. The greater per capita use of energy in Erie Co. relates to both of these factors plus the presence of may single-family detached houses, which are energy intensive.

U.S. GOVERNMENT PRINTING OFFICE: 614-090-\#12 